\title{
Description of a new Lithoxus (Siluriformes: Loricariidae) from the Guayana Highlands with a discussion of Guiana Shield biogeography
}

\author{
Nathan K. Lujan
}

Lithoxus jantjae, new species, is described from above Tencua Falls in headwaters of the Ventuari River, a white- to clearwater river flowing west from the Maigualida and Parima mountains in the Guayana Highlands of southern Venezuela. Lithoxus jantjae represents a nearly $600 \mathrm{~km}$ westward range expansion for a genus historically known only from Guyana, Suriname, French Guiana, and Brazil. Lithoxus jantjae shares with other species of Lithoxus a dorsoventrally depressed body and a large, papilose oral disk with small toothcups and few teeth. It can be distinguished from congeners by a unique combination of characters including 12 branched caudal-fin rays, medial premaxillary tooth cusps enlarged, and a convex posterior margin of the adipose-fin membrane. With the discovery of $L$. jantjae, Lithoxus becomes the most recent example of a growing list of rheophilic loricariid genera with disjunct distributions on east and west sides of the Guayana Highlands. A biogeographic hypothesis relying on the existence of a proto-Berbice River uniting the southern Guayana Highlands with rivers of the central Guiana Shield is advanced to partially explain the modern distribution of these species.

Lithoxus jantjae, espécie nova, é descrito da região acima das cachoeiras de Tencua, nas cabeceiras do rio Ventuari, um rio de águas brancas a claras que corre para o oeste das montanhas Maigualida e Parima nas Terras Altas de Guayana, sul da Venezuela. Lithoxus jantjae amplia em cerca de $600 \mathrm{~km}$ para o oeste a distribuição de um gênero historicamente conhecido somente da Guiana, Suriname, Guiana Francesa e Brasil. Lithoxus jantjae compartilha com outras espécies de Lithoxus o corpo deprimido e um disco oral grande e papiloso, com pequenos dentários e premaxilares e poucos dentes. Ele é distinguido dos congêneres por uma combinação única de caracteres incluindo 12 raios caudais medianos ramificados, cúspide medial dos dentes do premaxilar aumentada e uma margem posterior convexa na membrana da nadadeira adiposa. Com a descoberta de $L$. jantjae, Lithoxus torna-se o exemplo mais recente de uma lista de gêneros de loricariídeos reofílicos com distribuição disjunta nos lados leste e oeste das Terras Altas de Guayana. Uma hipótese biogeográfica baseada na existência de um rio protoBerbice unindo o sul das Terras Altas de Guayana com os rios do escudo central das Guianas é proposta a fim de explicar a distribuição moderna destas espécies.

Key words: Ancistrini, Endemism, Faunal barrier, Proto-Berbice.

\section{Introduction}

Lithoxus Eigenmann is a genus of seven small, rheophilic loricariids that are externally characterized by a strongly dorsoventrally depressed body, a large round oral disk, and small tooth cups with few teeth. Lithoxus range from the Oyapock drainage along the border between Brazil and French Guiana, through Suriname west to the Tacutu River along the border between Guyana and Brazil and south to the Uatuma and Trombetas rivers of Brazil (Boeseman, 1982; Muller \& Isbrücker, 1993; Ferreira, 1993; pers. obs.). Specimens referable to Lithoxus have not previously been reported from the Orinoco Basin, or anywhere west of the Branco River.

Lithoxus was strongly supported as a monophyletic sister to Exastilithoxus Isbrücker \& Nijssen, 1979 by Armbruster
(2004). The two genera can be distinguished by the absence of fimbriate papillae along the margin of the oral disk in Lithoxus. Together, Lithoxus and Exastilithoxus form a clade that is well diagnosed with external morphological, and internal osteological and visceral characters (Schaefer, 1987; Armbruster, 2004). Interspecific relationships within Lithoxus were first described by Boeseman (1982), who proposed the monotypic subgenus Lithoxus for L. lithoides based partly on fewer anal-fin rays (four $v s$. five), fewer interdorsal plates (5 vs. 6-8 in species with adipose fins), the presence of a membranous posterior extension of the adipose fin, and the lack of a distinct upper caudal-fin lobe. All other species were placed in the subgenus Paralithoxus (Boeseman, 1982) until Nijssen \& Isbrücker (1990) synonymized Boeseman's subgenera with their description of Lithoxus stocki. Since

Auburn University Fish Collection, 303 Funchess Hall, Auburn University, Auburn, AL 36849. 
Nijssen \& Isbrücker (1990), a single species, Lithoxus boujardi, has been added to the genus by Muller \& Isbrücker (1993).

A 2004 All Catfish Species Inventory expedition to the upper Orinoco in Amazonas, Venezuela collected an eighth, undescribed species of Lithoxus restricted to the upper Ventuari River above Tencua Falls. This species, representing a nearly $600 \mathrm{~km}$ westward range expansion for the genus Lithoxus, is described herein as Lithoxus jantjae.

\section{Materials and Methods}

Counts and measurements follow Armbruster (2003); measurements presented as ratios of either standard length (SL) or head length (HL). Names of plate rows follow Schaefer (1997). Institutional abbreviations are as listed at http:// research.calacademy.org/research/ichthyology/catalog/ abtabr.html. For all materials examined, numbers following catalog numbers are, first, the total number of specimens in the lot, then the range of standard lengths of specimens in the lot, then, in parentheses, number of specimens measured and standard lengths of these specimens, then locality, date of collection, and collectors. Specimens smaller than $29.0 \mathrm{~mm}$ SL not measured. Dorsal-fin spinelet, first unbranched dorsalfin ray, first unbranched pectoral-fin ray, first unbranched pelvic-fin ray, and dorsalmost and ventralmost unbranched caudal-fin rays treated as spines following Armbruster (2003). I follow Hammond (2005) in referring to those upland portions of the Guiana Shield in southeastern Venezuela, western Guyana, and northern Brazil as the Guayana Highlands.

Comparative material. Lithoxus lithoides, AUM 28018(1),AUM 35515 (1), AUM 35549 (10), AUM 35603 (1), AUM 35707 (1), AUM 37922 (1),AUM 37943 (1),AUM39001 (2),AUM39040 (6), AUM 38824 (1). Lithoxus bovallii, AMNH 54961 (8).

\section{Lithoxus jantjae, new species}

Fig. 1

Holotype. MCNG 55349, 38.4 mm SL, Venezuela, Amazonas, río Ventuari, above Tencua Falls $58 \mathrm{~km}$ ESE of San Juan de Manapiare, approx. 5²'N, 65³6'W, 21 Apr 2004, N. K. Lujan, O. León, A. Luna \& A. Yarumare.

Paratypes. Same data as holotype. ANSP 182809, 4, 21.4-33.7 mm SL (2, 30.6, 33.7 mm SL); AUM 39478, 4, 21.6-32.3 mm SL (1, $32.3 \mathrm{~mm} \mathrm{SL})$; MCNG 55350, 2, 22.1, $29.0 \mathrm{~mm} \mathrm{SL}$ (1, $29.0 \mathrm{~mm} \mathrm{SL})$.

Diagnosis. Lithoxus jantjae can be separated from all other Lithoxus by having 12 branched caudal-fin rays (vs. 14); from all Lithoxus except $L$. lithoides by having four branched analfin rays ( $v s$. five), and five interdorsal plates ( $v s$. six to eight when adipose fin present); from all Lithoxus except L. lithoides and $L$. stocki by having a convex posterior membranous extension of the adipose fin ( $v s$. adipose fin, when present, without posterior extension, posterior margin strait or concave); from all Lithoxus except $L$. lithoides and $L$. bovallii by having medial premaxillary teeth with an enlarged and widened cusp (vs. cusps of all premaxillary teeth similar in size, not enlarged); from all Lithoxus except L. lithoides, L. stocki and L. boujardi by having an obliquely truncate to slightly emarginate caudal fin ( $v s$. caudal fin obliquely forked with a distinct upper caudal lobe); from L. lithoides by having a mode of 24 supramedian plates ( $v s$. mode of 25 ) and a mode of 18 (range 16-25) hypertrophied cheek odontodes ( $v s$. mode of 12 , range five to 21 ); and from L. pallidimaculatus and L. surinamensis by having an adipose fin ( $v s$. adipose fin absent).

Description. Morphometrics in Table 1. Largest specimen 38.4 $\mathrm{mm}$ SL. Body dorsoventrally depressed; dorsal profile strongly convex from anterior tip of upper lip to nares, distinctly curved near snout tip; slightly convex from nares to dorsal-fin origin; nearly straight from latter point to adipose-fin origin and distinctly concave from latter point to caudal fin. Ventral profile somewhat straight from snout tip to caudal fin. Ventral profile flat to caudal fin. Caudal peduncle approximately triangular in cross section, with dorsal surface and ventrolateral corners rounded. Body widest at insertion of pectoral fins, narrowest at insertion of caudal fin. Snout rounded in dorsal view.

Eyes small, iris operculum absent. Interorbital surface flat with modest lateral rise at supraorbital crests. Supraoccipital not elevated. Odontodes along lateral margin of opercle enlarged.

Oral disk occupying entire ventral surface of head. Ventral surface of disk covered with low, wide papillae; margin of disk fringed with low triangular papillae. Maxillary barbel short and projecting laterally or somewhat anterolaterally from anterolateral corners of upper lip.

Median plates 24-25 (mode 24). Plates not keeled. Five caudal peduncle plate rows. Five interdorsal plates. Ventrum from anteroventral margin of snout to anus without plates. Evertible cheek plates supporting hypertrophied odontodes; odontodes evertible to approximately $90^{\circ}$ from longitudinal body axis. Hypertrophied cheek odontodes 16-25 (mode 18). Longest evertible cheek odontode extending slightly beyond anterior margin of cleithrum. Enlarged odontodes also present along anterodorsal surface of pectoral-fin spine, increasing in length distally.

Dorsal fin II,7; dorsal-fin spinelet V-shaped, dorsal-fin locking mechanism present, dorsal-fin origin approximately equidistant from snout and insertion of dorsal spine of caudal fin, dorsal fin not contacting adipose spine when adpressed. Adipose fin with single azygous preadipose plate, adiposefin membrane extending posteriorly beyond adipose-fin spine as a free flap with convex posterior margin. Caudal fin I, 12,I; caudal fin obliquely truncate to slightly emarginate, lower lobe longer than upper, dorsal procurrent caudal rays four, ventral procurrent caudal rays three. Pectoral fin I,6; pectoralfin spine reaching slightly beyond base of pelvic-fin spine when adpressed dorsal to pelvic fin. Pelvic fin I,5; pelvic-fin spine reaching slightly beyond base of anal fin when adpressed. Fin rays of dorsal, caudal, pectoral and pelvic fins 


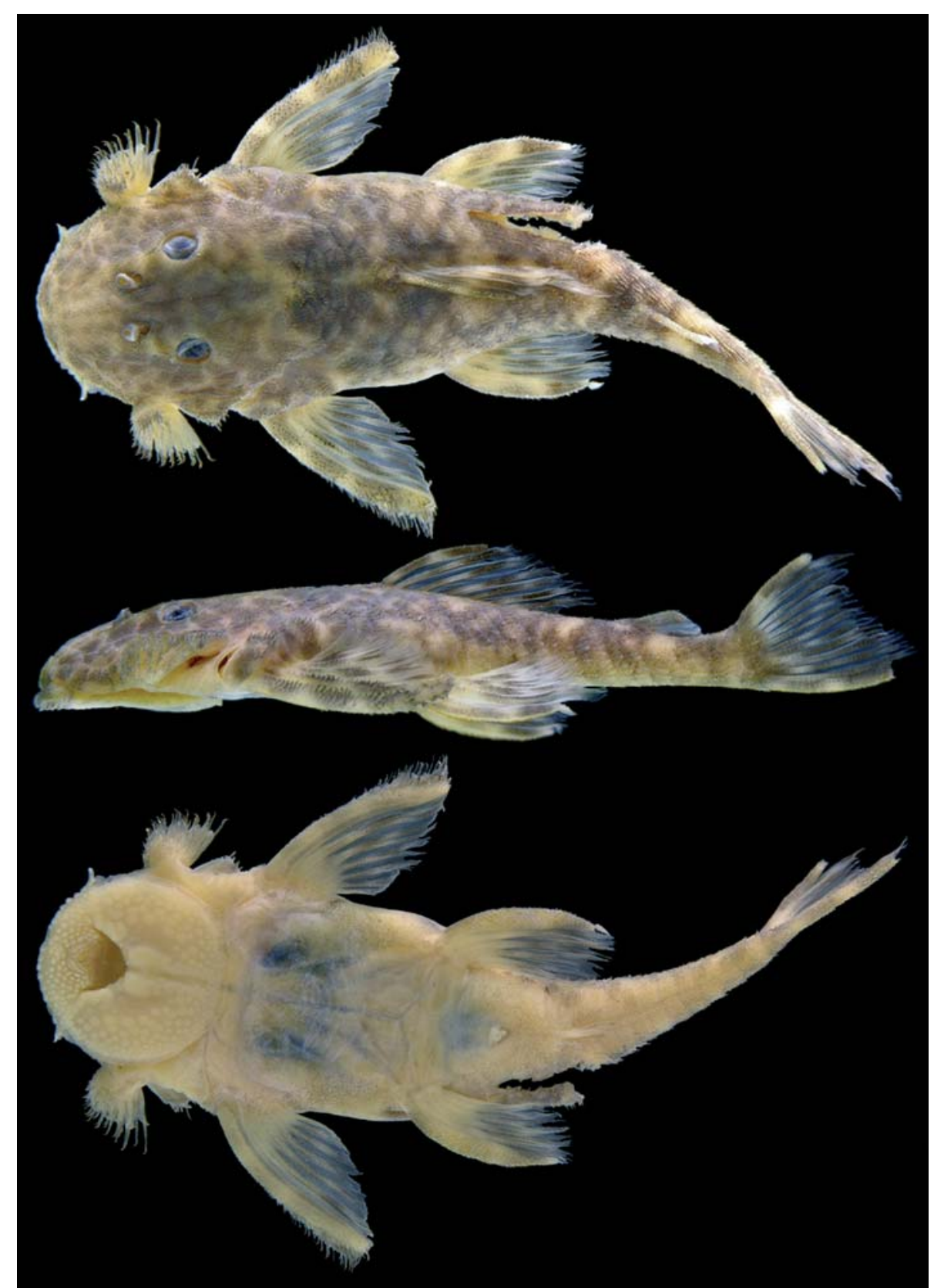

Fig. 1. Lithoxus jantjae, holotype, MCNG 55349, 38.4 mm SL, Venezuela, Amazonas State, Ventuari River upstream of Tencua Falls.

extending beyond fin membranes to form fimbriate posterior margins. Anal fin i,4. Anal papilla distinct.

Teeth bicuspid with deep division between cusps; two to five left premaxillary teeth (mode five), four to eight left dentary teeth (mode five); premaxillary tooth cusps increasing in size from lateralmost tooth to medialmost tooth with medialmost tooth cusp two to four times as large as lateralmost tooth cusp, lateralmost premaxillary tooth cusps similar in size to dentary tooth cusps.

Color in alcohol. Dorsum consisting of dark brown mottling on light brown to yellow base; mottling concentrated to form four indistinct saddles in most but not all specimens; pattern extends onto rays and spines of all but the anal fin; fin mem- branes transparent; plates of snout accentuated by dark center with lighter edges. Ventrum including oral disk uniformly light yellow to sand-colored.

Distribution. Known only from rapids that extend for a few hundred meters upstream of Tencua Falls, the first major faunal barrier in the Ventuari River (pers. obs.), a right bank tributary of the upper Orinoco in Amazonas State, Venezuela (Fig. 2).

Etymology. Matronym honoring the author's mother, nicknamed Jantje prior to her emigration from the Netherlands, in deep appreciation for her hard work and material and emotional encouragement that promoted his professional development and made this research possible. Pronounced yäntchi. 
Table 1. Morphometric data for Lithoxus jantjae and L. lithoides. Landmarks are as illustrated in Armbruster (2003).

\begin{tabular}{|c|c|c|c|c|c|c|c|c|c|}
\hline \multirow[b]{2}{*}{ Landmarks } & \multirow[b]{2}{*}{ Measurement } & \multicolumn{4}{|c|}{ Lithoxus jantje } & \multicolumn{4}{|c|}{ Lithoxus lithoides } \\
\hline & & Mean & SD & Min. & Max. & Mean & SD & Min. & Max. \\
\hline $1-20$ & SL & 32.8 & 3.6 & 29.0 & 38.4 & 38.2 & 7.4 & 26.8 & 38.4 \\
\hline $1-10$ & Predorsal length & 44.1 & 1.4 & 42.3 & 45.6 & 45.7 & 1.6 & 43.1 & 49.2 \\
\hline $1-7$ & Head length & 34.8 & 0.8 & 33.6 & 35.8 & 34.5 & 1.3 & 31.8 & 36.8 \\
\hline $7-10$ & Head-dorsal length & 8.3 & 1.0 & 6.8 & 9.4 & 11.1 & 1.9 & 7.9 & 12.8 \\
\hline $8-9$ & Cleithral width & 25.9 & 0.6 & 25.2 & 26.8 & 25.6 & 2.5 & 21.0 & 30.0 \\
\hline $1-12$ & Head-pectoral length & 29.0 & 0.4 & 28.6 & 29.5 & 29.7 & 1.8 & 25.9 & 33.2 \\
\hline $12-13$ & Thorax length & 23.8 & 2.1 & 22.3 & 27.2 & 26.0 & 1.6 & 22.4 & 28.8 \\
\hline $12-29$ & Pectoral-spine length & 25.8 & 0.9 & 24.8 & 26.9 & 29.8 & 3.4 & 21.4 & 33.0 \\
\hline $13-14$ & Abdominal length & 19.9 & 1.5 & 18.3 & 22.3 & 18.2 & 1.6 & 14.7 & 22.3 \\
\hline $13-30$ & Pelvic-spine length & 22.4 & 1.6 & 19.7 & 23.8 & 23.5 & 2.2 & 18.8 & 26.2 \\
\hline $14-15$ & Postanal length & 34.4 & 1.5 & 33.2 & 37.0 & 32.4 & 2.1 & 28.9 & 35.9 \\
\hline $14-31$ & Anal-fin spine length & 7.5 & 0.9 & 6.1 & 8.2 & 7.6 & 1.3 & 5.2 & 10.2 \\
\hline $10-12$ & Dorsal-pectoral distance & 24.0 & 1.3 & 22.1 & 25.2 & 25.5 & 2.2 & 20.6 & 29.9 \\
\hline $10-11$ & Dorsal spine length & 19.7 & 1.4 & 17.7 & 21.3 & 20.9 & 2.5 & 17.3 & 26.8 \\
\hline $10-13$ & Dorsal-pelvic distance & 13.8 & 0.5 & 13.0 & 14.4 & 13.8 & 2.2 & 9.5 & 17.4 \\
\hline $10-16$ & Dorsal-fin base length & 27.2 & 1.6 & 24.6 & 28.7 & 24.2 & 2.3 & 20.3 & 28.7 \\
\hline $16-17$ & Dorsal-adipose distance & 6.5 & 0.5 & 5.7 & 7.0 & 11.0 & 2.3 & 5.7 & 14.5 \\
\hline $17-18$ & Adipose-spine length & 11.9 & 0.8 & 10.6 & 12.7 & 9.3 & 1.6 & 5.9 & 12.7 \\
\hline $17-19$ & Adipose-up. caudal distance & 20.3 & 1.2 & 18.9 & 22.0 & 18.7 & 2.2 & 16.1 & 24.2 \\
\hline $15-19$ & Caudal peduncle depth & 7.2 & 0.3 & 6.8 & 7.6 & 7.7 & 1.1 & 5.4 & 9.6 \\
\hline $15-17$ & Adipose-low. caudal distance & 25.4 & 1.9 & 22.3 & 26.9 & 22.3 & 2.1 & 18.1 & 28.2 \\
\hline $14-17$ & Adipose-anal distance & 14.6 & 0.9 & 13.7 & 15.9 & 14.7 & 1.4 & 11.9 & 16.4 \\
\hline $14-16$ & Dorsal-anal distance & 10.5 & 1.1 & 9.3 & 11.8 & 9.3 & 1.2 & 7.2 & 11.8 \\
\hline $13-16$ & Pelvic-dorsal distance & 27.6 & 1.9 & 25.3 & 30.0 & 21.5 & 2.2 & 17.9 & 30.0 \\
\hline $5-7$ & Head-eye length & 41.1 & 1.7 & 38.3 & 42.7 & 40.5 & 2.8 & 35.8 & 45.1 \\
\hline $4-5$ & Orbit diameter & 14.1 & 1.2 & 12.4 & 15.6 & 20.0 & 3.0 & 13.7 & 25.9 \\
\hline $1-4$ & Snout length & 51.9 & 2.6 & 49.8 & 56.0 & 53.0 & 2.2 & 47.6 & 56.8 \\
\hline $2-3$ & Internares width & 9.3 & 1.5 & 7.4 & 10.8 & 14.0 & 2.6 & 9.9 & 18.1 \\
\hline $5-6$ & Interorbital width & 30.1 & 1.7 & 28.4 & 32.1 & 33.8 & 3.9 & 29.0 & 42.6 \\
\hline $7-12$ & Head depth & 55.2 & 3.6 & 50.2 & 59.5 & 57.0 & 6.3 & 37.3 & 64.1 \\
\hline $1-24$ & Mouth length & 67.4 & 1.6 & 65.5 & 69.3 & 53.8 & 5.0 & 46.7 & 68.4 \\
\hline $21-22$ & Mouth width & 69.7 & 1.6 & 68.1 & 71.8 & 61.7 & 4.3 & 50.3 & 69.7 \\
\hline $22-23$ & Barbel length & 8.5 & 1.9 & 6.3 & 10.5 & 10.6 & 2.5 & 6.7 & 13.3 \\
\hline $25-26$ & Dentary tooth cup length & 15.1 & 2.1 & 12.5 & 17.8 & 12.8 & 2.8 & 9.1 & 16.5 \\
\hline $27-28$ & Premaxillary tooth cup length & 14.5 & 1.9 & 11.3 & 16.0 & 9.7 & 2.5 & 7.3 & 16.0 \\
\hline
\end{tabular}

\section{Discussion}

Lithoxus jantjae has fewer branched caudal-fin rays (12 vs. 14) than any congener, clearly diagnosing it as a new species. Additionally, it has five characters shared with only a few congeners: four anal-fin rays and five interdorsal plates (shared only with $L$. lithoides), enlarged medial premaxillary tooth cusps (shared with $L$. lithoides and L. bovallii), a convex posterior expansion of the adipose-fin membrane (shared with L. lithoides and $L$. stocki), and an obliquely truncate to slightly emarginate caudal fin (shared with L. lithoides, L. stocki and possibly L. boujardi). Based on overall appearance (Fig. 3), and the shared presence of only four anal-fin rays, five interdorsal plates, enlarged medial premaxillary tooth cusps, a convex posterior extension of the adipose fin, and an obliquely truncate to slightly emarginate caudal fin, it seems that $L$. jantjae is most closely related to $L$. lithoides. The existence of a second species more closely related to $L$. lithoides than to all other Lithoxus strengthens the argument by Boeseman (1982) that the genus comprises two subgenera: Lithoxus and Paralithoxus, with L. jantjae and L. lithoides in the former, and all remaining species in the latter. This putatively close phylogenetic relationship is also consistent with their geographic proximity, L. lithoides being the closest Lithoxus species east of the apparent distribution gap separating $L$. jantjae from all congeners.

With the discovery of Lithoxus jantjae, Lithoxus becomes the most recent example of a growing list of rheophilic loricariid genera with apparently disjunct distributions on opposite sides of the Guayana Highlands. Exastilithoxus, the sister genus of Lithoxus, is represented by E. hoedemani in the Marauiá River, a tributary of the upper Negro near the southwestern border between Venezuela and Brazil, and by E. fimbriatus in the upper Caroni in southeastern Venezuela. Neblinichthys is represented by N. pilosus from the Baria River, a tributary of the lower Casiquiare in extreme southwestern Venezuela and by $N$. yaravi from tributaries of the upper Caroni River in the southeastern corner of Venezuela. Harttia is represented by H. merevari in the upper Caura and upper Ventuari rivers (sympatric with L. jantjae in the Ventuari) and by $H$. platystoma in the Essequibo River. Lithogenes, which is either the sister group to all remaining 
loricariids (Schaefer, 2003) or a genus of the Astroblepidae (Armbruster, 2004), is represented by an undescribed species from the Cuao River, a right bank tributary of the upper Orinoco in northern Amazonas State, Venezuela (S. Schaefer, pers. com.), and by $L$. villosus in the upper Potaro River, a left bank tributary of the middle Essequibo River flowing off the eastern edge of the Guayana Highlands. In none of these genera are species known to exist in intervening drainages, suggesting either an intriguing biogeographic phenomenon or merely the paucity of collections in the central Guayana Highlands.

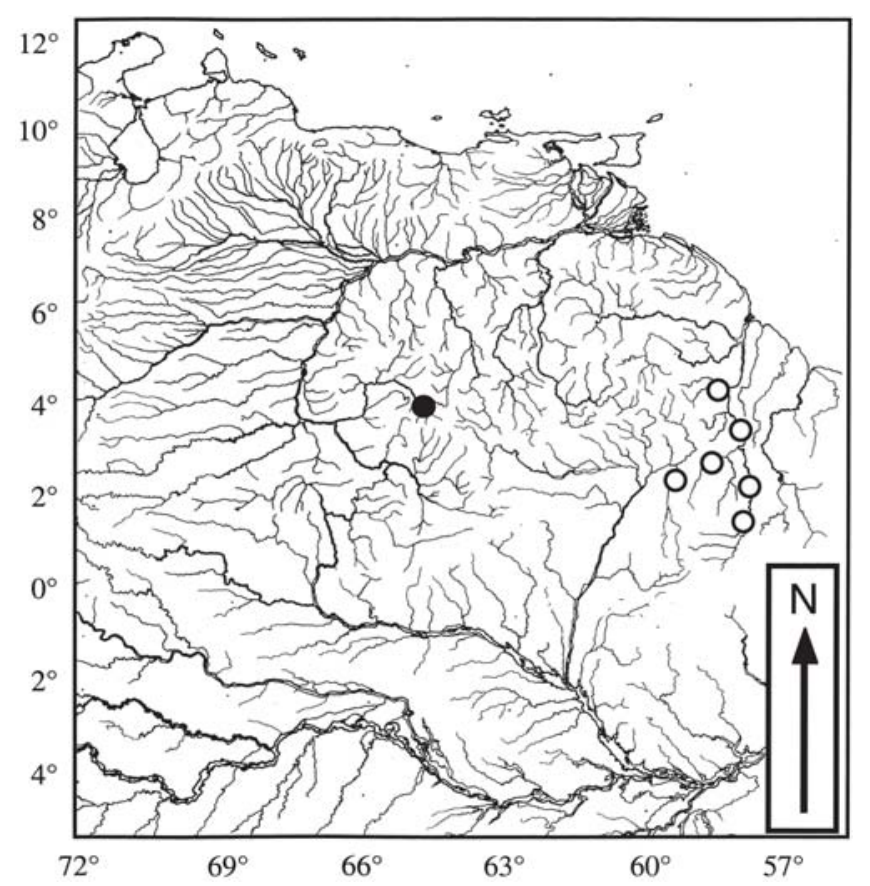

Fig. 2. Distribution of Lithoxus jantjae (filled circle) and $L$. lithoides (open circles), the geographically closest described species of Lithoxus.
While it is true that headwaters of the Orinoco, Ventuari, Caura, Caroni, and Uraricoera rivers draining the central Guayana Highlands are poorly collected, a biogeographic hypothesis could be advanced that might partially explain the historical origin of these now apparently relictual populations. Several geologists (e.g. Sinha, 1968; McConnell et al., 1969; Berrangé, 1975; Schaefer \& do Vale, 1997) have hypothesized that for most of the last $65 \mathrm{My}$ a single river drained the Guayana Highlands's southern slope to the Atlantic Ocean via a main channel that flowed through the North Rupununi Savannas and exited to the Atlantic near the mouth of the modern Berbice River. They called this river the proto-Berbice. These same authors, and others (e.g. Gibbs \& Barron, 1993), describe periods of uplift of the Guiana Shield in which watershed boundaries shifted due to tilting of the underlying basement, rejuvenation of river channels, headcutting, and consequent stream piracy. A drainage map of the Guayana Highlands (Fig. 2) shows several strongly recurved elbows of capture in the upper Caroni, Caura, and Erebato (Caura) rivers supporting historical confluence of these headwaters with the southeasterly flowing upper proto-Berbice (modern Uraricoera River). Geographically restricted populations of rheophilic fishes endemic to the western side of the Guayana Highlands may have once been united with congeners to the east via headwaters of the proto-Berbice. Under this scenario, proto-Berbice headwaters would have been lost to west- and north-flowing rivers via stream piracy, and these separations reinforced by further uplift of the Guiana Shield. Alternative explanations for these disjunct distributions requiring recent radiation via mainstem river connection are contraindicated by the absence of collections from intervening mainstem habitats, and by the rheophilic requirements of the taxa exemplified.

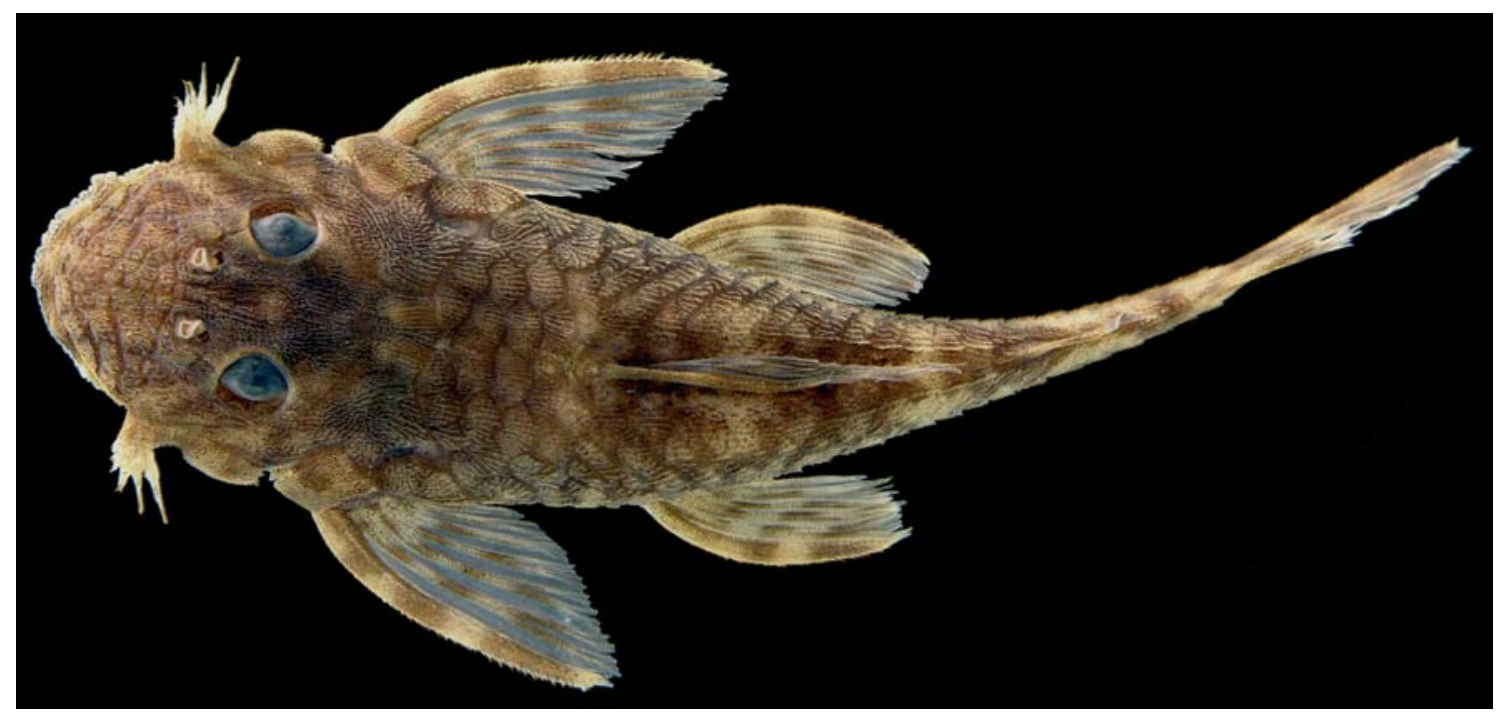

Fig 3. Lithoxus lithoides, AUM 39040, 49.0 mm SL, Guyana, Essequibo River at Yukanopito Falls. 


\section{Acknowledgements}

I gratefully acknowledge J. W. Armbruster for financial and logistical support of this research; D. Taphorn and O. León for assistance in obtaining permits, and indispensable logistical support in Venezuela. This project was funded by Planetary Biodiversity Inventory: All Catfish Species (Siluriformes) — Phase I of an Inventory of the Otophysi, a 5 year grant through the US National Science Foundation to describe all species of catfishes (NSF DEB-0315963) and NSF grant DEB-0107751 to J. W. Armbruster.

\section{Literature Cited}

Armbruster, J. W. 2003. Peckoltia sabaji, a new species from the Guyana Shield (Siluriformes: Loricariidae). Zootaxa, 344: 1-12.

Armbruster, J. W. 2004. Phylogenetic relationships of the suckermouth armoured catfishes (Loricariidae) with emphasis on the Hypostominae and the Ancistrinae. Zoological Journal of the Linnaean Society, 141: 1-80.

Berrangé, J. P. 1975. The geomorphology of southern Guyana with special reference to the development of planation surfaces. Anais Décima Conferência Geológica Interguianas, 1: 804-824.

Boeseman, M. 1982. The South American mailed catfish genus Lithoxus Eigenmann, 1910, with the description of three new species from Suriname and French Guyana and records of related species (Siluriformes, Loricariidae). Proceedings of the Koninklijke Nederlandse Akademie van Wetenschappen - Series C: Biological \& Medical Sciences, 85: 41-58.

Gibbs, A. K. \& C. N. Barron. 1993. The geomorphology of the Guiana Shield and the Phanerozoic geology of its periphery. Pp. 170-179 In: The Geology of the Guiana Shield, Oxford Monograph on Geology and Geophysics. Oxford University Press, Oxford.
Hammond, D. S. 2005. Biophysical features of the Guiana Shield. Pp. 15-194 In: D. S. Hammond (Ed.). Tropical Forests of the Guiana Shield. CABI, Cambridge.

McConnell, R. B., D. Masson Smith \& J.P. Berrange. 1969. Geological and geophysical evidence for a rift valley in the Guiana Shield. Geologie en Mijnbouw, 48: 189-199.

Nijssen, H. \& I. J. H. Isbrücker. 1990. Lithoxus stocki, a species new to science of ancistrin loricariid catfish from the Maroni River drainage, with a comparison of the primary type specimens of the six species of Lithoxus (sy.: Paralithoxus) (Pisces, Siluriformes, Loricariidae). Bijdragen tot de Dierkunde, 60: 327-333.

Schaefer, C. E. R. \& J. F. do Vale Jr. 1997. Mudanças climáticas e evolução da paisagem em Roraima: uma resenha do Cretáceo ao Recente. Pp. 231-265 In: R. I. Barbosa, E. J. G. Ferreira \& E. G. Castellón (ed.). Homem, Ambiente e Ecologia na Estado de Roraima. INPA, Manaus, Brazil.

Schaefer, S. A. 1987. Osteology of Hypostomus plecostomus (Linnaeus), with a phylogenetic analysis of the loricariid subfamilies (Pisces: Siluriformes). Contributions in Science, Natural History Museum of Los Angeles County, 394: 1-31.

Schaefer, S. A. 2003. Relationships of Lithogenes villosus Eigenmann, 1909 (Siluriformes, Loricariidae): evidence from highresolution computed microtomography. American Museum Novitates, 3401: 1-26.

Sinha, N. K. P. 1968. Geomorphic evolution of the Northern Rupununi Basin, Guyana. McGill University Savanna Research Project, Savanna Research Series 11, McGill University, Montreal.

Accepted July, 2008

Published September 30, 2008 